\title{
Sykehusdrift og vårt daglige brød
}

\author{
Alle sykehuspasienter som er i stand til å spise, må få den maten de trenger mens de er inn- \\ lagt. Selv om det stadig blir ansatt nye administratorer og hyret inn flere og flere konsulenter \\ i sykehusvesenet, har dette allmenngyldige prinsippet hittil ikke blitt satt under debatt som et \\ viktig ressursmål.
}

Innlagte pasienter på norske sykehus må selvsagt ha mat. Derimot får helsepersonalet værsågod holde seg med maten selv, uansett hvor sultne eller trøtte de måtte bli. Selv om det av og til kan være vanskelig å se hvem som er lege og hvem som er pasient på en travel avdeling, kan dette skillet føre til at matinntak hos pasientene betegnes som en spesifikk omsorgsrelatert aktivitet. Riktignok faller de som er på kunstig ernæring klart utenfor den spisende pasientpopulasjonen, men da er denne ernæringen å betegne som terapi. Derav følger at absolutt alle de personer på et stort sykehus som reelt spiser, har vært i stand til å spise eller som i løpet av behandlingsperioden kan bli i stand til å spise interne brødskiver, er å betegne som pasienter. Ikke nok med det, men totalt antall brødskiver som går med, kan være et pålitelig mål for total pasientaktivitet. Mengden brødskiver per pasient per døgn fremstår da som et potensielt ressursmål.

Han som oppdaget dette prinsippet er en av de førende skikkelsene innen norsk sykehusvesen, nevrologen Ragnar Stien. Han hadde arbeidet i flere tiår ved Rikshospitalet og Ullevål sykehus, inntil han ble emeritert for noen år siden. For å fastsette en såkalt døgnpris som ressursmål har man hittil brukt antall anvendte sengeplasser. Det er nokså upålitelig: Noen pasienter ligger i senga hele tiden, noen står stadig opp og går ut og noen befinner seg der bare om natten og knapt nok det. Derfor hastet det med å finne nye og mer brukbare mål for ressurser som har gått med til driften. Få personer kjenner innsiden til norsk sykehusvesen bedre enn Ragnar Stien, og allerede i 2001 kom han med det epokegjørende forslaget å omdefinere døgnprisbegrepet til det mer spesifikke ressursmålet «skivepris», det vil si mengden totalressurser som ligger bak én fortært brødskive per pasient per døgn. Denne ideen ga han helt gratis til den store hæren av «bokholdere» som utreder og styrer norsk sykehusvesen. Skivepris er dessuten et begrep som er lett å skjønne for politikere som skal bestemme ressurstilgangen til norske sykehus. Det er innlysende at dersom det ikke serveres brødskiver, så kommer det heller ingen pasienter. Og de pasientene som allerede er der, vil forsvinne raskt av seg selv hvis de blir uten mat.

For egen del vil jeg tilføye at økte resultatkrav til leger og øvrig pleiepersonell fører til stadig nedkorting av de reelle spisepausene. Da får institusjonen mer ut av kostbar arbeidstid hos spesialisert personell med høyt lønnsnivå. At personalet ikke rekker å spise den medbrakte matpakken med ferdig påsmurte privatbrødskiver, gir likevel neppe noen besparelser i sykehusets driftsbudsjett. Dette kompliserte saksforholdet er også noe å tenke over hos de nevnte bokholderne.

\section{Ole Didrik Lærum}

ole.laerum@gades.uib.no

Ole Didrik Lærum (f. 1940) er professor (adj.) ved Københavns Universitet og professor emeritus ved Universitetet i Bergen.

\section{Skivepris - et forsøk på å bedre økonomistyringen i norske sykehus}

\author{
Stien R. Skivepris - et forsøk på å bedre økonomistyringen i norske sykehus. Tidsskr Nor Lageforen 2001; 121: 1132.
}

Krise er en stadig tilbakevendende - eller kanskje kronisk - tilstand i norsk helsevesen. Årsakene til denne urovekkende situasjon er flere, men økonomi - ingen eller manglende styring av samme - er oftest angitt som grunn. Leger blir beskyldt for manglende interesse for økonomi, en påstand som kan synes berettiget. I alle fall er styringen av norsk helsevesen overlatt til bokholdere. Begreper fra økonomisk teori brukes til å male effektivitet, kostnader, kvalitet og faglig standard på helsetjenester. Leger har tradisjonelt hatt vansker med å forstå hvordan disse økonomiske begreper, f.eks. lønnsomhet, kan appliseres på behandling av syke.

I denne artikkelen drøftes muligheten av å bruke et bedre og mer forståelig økonomiske verktøy for å måle kostnader ved sykehusdrift.

\section{Døgnprisbegrepet}

For enkelt å kunne gi et bilde av kostnadene ved sykehusdrift har bokholderne innført begrepet «døgnpris».
Døgnprisen beregnes ut fra den økonomiske formelen: $\mathrm{a} / \mathrm{b}=$ døgnpris, hvor $\mathrm{a}$ er sykehusets samlede kostnader i ett år (lønn til helsearbeidere, medisiner, utstyr, snømåking og bokholderiutgifter) og b er det totale antall pasientovernattinger i seng det samme år. Døgnprisen varierer noe fra sykehus til sykehus, men et godt bilde gir refusjonsbeløpet per natt i medisinske avdelinger i et regionsykehus, som er 3000 3500 kroner. Den reelle døgnprisen er vanligvis minst det dobbelte av refusjonsbeløpet. 
De fleste politikere (som har enda større problemer med å forstå økonomiske begreper enn leger) har den klare oppfatning at dette er en uhyrlig pris for å ligge $i$ en seng $i$ ett døgn. Et resultat av denne oppfatningen er at antall sykehussenger søkes redusert for å redusere kostnadene ved sykehusdriften (1).

Mange av landets borgere bibringes også den oppfatning at den dårlige økonomistyringen i sykehus gjør det billigere å overnatte på luksushotell enn å overnatte i en ubekvem sykehusseng på et rom med tre andre. De fleste sykehusklinikere føler seg uvel ved døgnprisbegrepet fordi den høye verdien bidrar til å fjerne senger fra sykehusene. Klinikere har fortsatt den noe gammelmodige forestilling at sykehus bør ha senger, jf. at klinikk kommer fra gresk kline $=$ seng

\section{Behov for nytt kostnadsbegrep?}

Ved Nevrologisk avdeling, Ullevål sykehus, har vi lenge vært misfornøyd med døgnpris som mål for kostnadene ved avdelingens drift. Ingen ved avdelingen har formell økonomisk kompetanse, men enkle beregningsmetoder (papir og blyant) antydet at en antatt døgnpris på 6 000-7 000 kroner for selve overnattingen $i$ avdelingen var noe høy. Faktisk kom vi, noe overraskende, til at en overnatting $i$ et nokså snuskete tremannsrom med en vask, ett toalett i gangen delt med ti andre og en dusj lenger borte i gangen delt med ytterligere ti var billigere enn noe annet overnattingstilbud i kongeriket - ungdomsherberger inklusive (2). Disse resultatene gjorde at vi fant å måtte forkaste døgnpris som økonomisk verktøy. Vi har så forsøkt å finne et annet mål for kostnadene som er like logisk og enkelt som døgnpris, men som vektlegger andre sider ved sykehusdriften. Et slikt nytt økonomisk begrep må

- være enkelt (slik at bokholdere og politikere kan forstå det)
- være knyttet til en typisk sykehusaktivitet (som å sove i seng)

- være like logisk og egnet til å vurdere totale sykehuskostnader som døgnprisen

\section{Skivepris}

Etter omfattende prøving har vi funnet at «skivepris» er det best egnede begrep. Skiveprisen er enkel å beregne. Følgende formel benyttes: skivepris $=\mathrm{K} /$ Ask, hvor $\mathrm{K}$ er samtlige kostnader i sykehuset i et gitt år og Ask det totale antall brødskiver fortært av pasientene i samme år. Stikkprøver ved

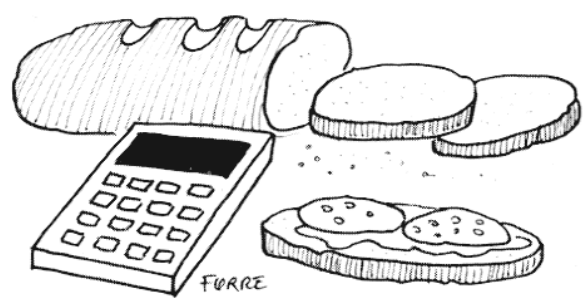

sykehusets hovedkjøkken har vist at tallet er lett å registrere (3). Inntak av brødskiver er en vel så typisk aktivitet som sengeligging, jf. at også dagpasienter spiser, noe som ikke blir fanget opp av døgnprisberegninger. For eget sykehus fremkommer følgende for år 2000: Skivepris $=k r 3116726000$ (4) dividert
med 2737000 brødskiver (3) =kr 1 138,74

Denne prisen synes uhyggelig høy. Riktignok kan noen av de tilberedte brødskiver være spist av ansatte ved sykehuset. Ettersom det er forbudt for ansatte å spise tiloversblevne skiver, går vi ut fra at dette tallet er meget lavt og neppe vil forrykke den beregnede skivepris vesentlig. I et langvarig sideprosjekt undersøkte vi smørbrødprisene ved flere anerkjente restauranter i Oslo-området. Prisen på en skive (av betydelig bedre kvalitet enn det som serveres ved Ullevål sykehus (egne iakttakelser 1997-2001), oversteg ikke kr 100 (5-7).

Vi vil hevde at resultatet av våre undersøkelser viser at skivepris er et velegnet verktøy for vurderingen av kostnader i sykehus. En umiddelbar konsekvens må bli at forbruket av brødskiver i norske sykehus må reduseres (mens sengetallet bibeholdes). Redusert sengetall går utover dårlige pasienter, som må plasseres i korridorene. Redusert brødskiveforbruk går utover de friskeste pasientene (som spiser mest). For ikke å komme $i$ et uføre med utsulting av pasientene må andre levnedsmidler introduseres. I den forbindelse vil vi minne om den fremsynthet som dronning Maria-Antoinette (1755-93) av Frankrike viste på et tidspunkt like før den franske revolusjon. Hun ble fortalt at folket ikke hadde brød og repliserte: «Kan de ikke i stedet spise kaker?» Vi går ut fra at våre beregninger av prisen på brødskiver i norske sykehus vil ha den effekt at pasientene heller tar kaker for å holde kostnadene nede. Vi mener også at med innføringen av begrepet «skivepris» har vi vist at norske leger kan yte vesentlige bidrag til utviklingen av økonomiske verktøy i helsevesenet.

Ragnar Stien Nevrologisk avdeling Ullevål sykehus 0407 Oslo

Litteratur

1. Nicolaysen KG. Innlagt eller utskrevet til pasienthotell? Tidsskr Nor Lægeforen 1997; 117: 3129-31.

2. Stien R. Et forsvar for sengen. Tidsskr Nor Lægeforen 1996; 16: 402

3. Ridderholt A. Årsforbruket av brød og brødskiver ved Ullevål sykehus. Oslo: Sentralkjøkkenet, Ullevål sykehus, 2001

4. Sluttregnskap for Ullevål sykehus 2000. Oslo: Oslo kommune, 2001.

5. Grillen. Menu. Oslo: Restaurant Bristol, 2000

6. Smørbrødliste. Oslo: Grand Café, 2000.

7. A la carte-meny. Oslo: Theatercafeen, 2000 